DOI: https://doi.org/10.32838/2523-4803/70-4-15

удК 338.3:658.5.011

\title{
Бойченко К.С.
}

кандидат економічних наук,

доцент кафедри бізнес-економіки та підприємництва,

ДВНЗ «Київський національний економічний університет

імені Вадима Гетьмана»

\section{Boichenko Kateryna}

SHEE «Kyiv National Economic University named after Vadym Hetman»

\section{ІНСТИТУЦІОНАЛЬНЕ ЗАБЕЗПЕЧЕННЯ ІНТЕГРОВАНОГО РОЗВИТКУ ПІДПРИЕМСТВ ЛЕГКОЇ ПРОМИСЛОВОСТІ}

Метою дослідження є визначення напрямів підвищення ефективності інституціонального забезпечення державного регулювання інтегрованого розвитку вітчизняних підприємств легкої промисловості з урахуванням зарубіжного досвіду. Встановлено, що в крайнах-лідерах галузі, щзо розвиваються, легка промисловість була оголошена пріоритетним напрямом для розвитку національної економіки. Запропоновано авторське бачення інституційного забезпечення державного регулювання інтегрованого розвитку підприсмств легкої промисловості України. Сформовано рекомендації щуодо підвищення рівня інституціонального забезпечення інтегрованого розвитку вітчизняних компаній. Визначено низку можливостей, які дає змогу реалізувати інституціональне забезпечення розвитку підприємств легкої промисловості в контексті його інтегрованості.

Ключові слова: інтегрований розвиток, інституціональне забезпечення, конкуренція, ефективність, управління.

Постановка проблеми. Процес удосконалення інтегрованого розвитку підприємств легкої промисловості є ключовим фактором інституційного економічного перетворення. Залежно від поставлених цілей підприємства можуть підвищувати свою внутрішню інтегрованість, а також об'єднуватися в інтегровані господарські кластери та комплекси на принципах концентрації виробництва та капіталу. Переваги від таких перетворень, спрямованих на зовнішню інтегрованість бізнесу, досягаються шляхом об'єднання підприємств різних організаційно-правових форм для досягнення спільних цілей. При цьому важливим $є$ завдання не лише підвищення рівня потенціалу перспективних зв'язків, але і їх розвитку, поглиблення інтегрованості технологічно пов'язаних виробництв, переорієнтації економічних інтересів і мотивів поведінки суб'єктів господарювання. Все потребує урахування пріоритетності інституціонального забезпечення розвитку вітчизняних компаній.

Аналіз останніх досліджень і публікацій. Б. Гардас, Р. Раут, Б. Нархеде [1. с. 98], Н. Заріцька [2, с. 129], В. Копельчук [3, с. 288] підкреслюють, що відсутність ефективної державної політики і погана інфраструктура є значними бар'єрами, які вимагають максимальної уваги з боку осіб, що приймають рішення, для досягнення стійкості в розвитку текстильної та швейної промисловості.

В. Цай [4, с. 2072] вважає, що з на основі впровадження Індустрії 4.0. на підприємствах легкої промис- ловості відбувається не тільки оптимізація виробничих процесів, а й ефективний контроль промислового забруднення за допомогою обслуговування даних i моніторингу. Л. Дейнеко, О. Кушніренко, О. Ціпліцька [5, с. 9] підтверджують, що цьому також повинна сприяти інституційна підтримка компаній.

К. Мунір, М Айяз, Д Леві, Х Вілмотт [6, с. 564], В. Федорак [7, с. 231], Л. Збаразська [8, с. 12] вивчають роль мережі корпоративних, державних, багатосторонніх і громадських організацій, які виступають посередниками в управлінні глобальними виробничими мережами текстильних компаній у процесі їхнього інтегрованого розвитку.

Сучасні дослідники М. Мохуддін, М. Рашид, М. Аль Азад, Су 3. [9, с. 86] розглядають підтримку бекшорінгу або решорінгу, як ключових детермінант виробничого інтегрованого оффшорінгу з країн, що розвиваються в країни з нижчим рівнем розвитку.

Ю. Огай, Ю. Мацумура, Й. Хошино [10, с. 12] аналізують переваги мережевої організації праці в межах японських бізнес-груп (кейретцу), акцентують увагу на їхній соціальній і економічній ефективності, пояснюючи іiі об'єднанням форм патерналізму з високою ефективністю ділової поведінки персоналу, зайнятого на різних рівнях організації в межах великих текстильних компаній і їхніх більш дрібних сателітів.

У нашому розумінні інституціональне забезпечення розвитку в контексті інтегрованості підприємств передбачає зміну внутрішньогалузевої структури виробництва 
в напрямі збільшення випуску різноманітного асортименту виробів, конкурентоспроможних як на внутрішньому, так і на світовому ринках, мобілізацію оборотних коштів і здійснення єдиної інвестиційної промислової політики держави, що дає змогу зробити виробництво конкурентоспроможним. Це зумовлює необхідність формування механізмів аналізу, планування і стимулювання ефективності розвитку підприємств легкої промисловості. Однак, незважаючи на активне звернення до підвищення рівня інституціонального забезпечення, слід відзначити недостатній рівень досліджень у напрямі саме інтегрованого розвитку підприємств.

Формулювання цілей статті. Велика значущість зазначеної проблеми для вітчизняної легкої промисловості визначила вибір напряму цього дослідження, необхідність осмислення, розроблення і використання нетрадиційних підходів до вирішення наявних і потенційних проблем підвищення ефективності інтегрованого розвитку компаній у легкій промисловості. Це зумовило мету цього дослідження - визначення напрямів підвищення ефективності інституціонального забезпечення державного регулювання інтегрованого розвитку вітчизняних підприємств легкої промисловості з урахуванням зарубіжного досвіду.

Виклад основного матеріалу дослідження. Opiєнтація виробництва на стабільну й ефективну діяльність спрямована на вдосконалення та підвищення ефективності функціонування підприємств легкої промисловості з урахуванням факторів зовнішнього конкурентного середовища, з одного боку, і внутрішніх особливостей конкретного виробництва - 3 іншого. При цьому довгострокові інтереси держави диктують необхідність розвитку вітчизняної індустрії легкої промисловості, які зумовлені такими факторами:

- по-перше, легка промисловість України традиційно орієнтована на внутрішній ринок і з об'єктивних обставин, пов'язаних із забезпеченням умов життєдіяльності людини, завжди має певний рівень попиту;

- по-друге, легка промисловість повинна вирішити завдання самозабезпечення України найважливішими видами тканин, одягу і взуття для населення і речового майна для силових структур, що дасть змогу усунути загрозу економічній безпеці країни.

Процес удосконалення інтегрованого розвитку підприємств легкої промисловості виступає як фактор інституційного економічного перетворення. Залежно від поставлених цілей підприємства можуть об'єднуватися в інтегровані господарські кластери та комплекси на принципах концентрації виробництва й/ або концентрації капіталу. Переваги від таких перетворень досягаються шляхом інтеграції, яка передбачає об'єднання підприємств різних організаційно-правових форм для досягнення спільних цілей.

Світовий досвід інституціонального забезпечення розвитку легкої промисловості демонструє основні характерні риси. Можливими шляхами застосування цього досвіду в Україні є характеристики розвитку легкої промисловості в окремих країнах.
Наприклад, у Німеччині підтримується тісний зв'язок текстильної про-мисловості 3 національними банками: «Bayerische Hypo-und Vereinsbank AG» (HVB), «Deutsche Bank AG», «Commerzbank AG» i «Dresdner Bank AG» [11, с. 5]. Вони активно взаємодіють щодо фінансування виробничих компаній. Банки беруть участь не тільки у фінансуванні інвестиційних проектів, а й в управлінні підприємствами. Німецькі текстильні компанії почали все більше впроваджувати схему, що базується на співробітництві з країнами СНД. Певною мірою це формує інтегрованість, яка отримала згодом назву «толінг», дала змогу скоротити витрати на робочу силу, що відобразилося на ціні кінцевої продукції. Подібне внутрішне фінансування не може бути застосоване у вітчизняних умовах повною мірою, у зв'язку з обмеженістю банківських ресурсів. Однак інтегрованість 3 європейськими фінансово-промисловими групами дасть змогу привести технології виробництва текстильних товарів до світових стандартів.

У країнах Південно-Східної Азії інституціональне забезпечення інтегрованого розвитку підприємств легкої промисловості формується за рахунок залучення транснаціональних компаній та іноземних інвестицій, створення замкнутого технологічного циклу, оснащення сучасним високопродуктивним обладнанням, здійснення прямої підтримки експортерів, звільнення виробників від сплати митних зборів і податку на додану вартість на ввезену сировину і обладнання, а також розроблення та використання Кодексів корпоративної поведінки та етичних кодексів [12, с. 59].

Так, в Японії є такі мережеві структури: горизонтальні (між великими компаніями) та вертикальні (кейретцу), побудовані навколо великої спеціалізованої індустріальної корпорації, що охоплює значну кількість постачальників. Урядові банки та підконтрольні уряду торгові компанії підтримують центральну холдингову компанію [10, с. 7].

Для країн Східної Європи характерне розукрупнення підприємств, що супроводжується скороченням виробничих потужностей і зайнятості, кооперування 3 великими іноземними компаніями за допомогою виконання субпідрядних робіт (толінг), гарантія можливості репатріації прибутку і дивідендів після сплати податків, звільнення від сплати митних зборів основних засобів, що надходять як інвестиції у статутний фонд компанії, поступове зниження ставки рефінансування, девальвація національної валюти щодо євро, а також пошук нових зовнішніх ринків і проведення успішної лібералізації банківського сектору [13, с. 276].

Практика залучення ресурсів американськими текстильними компаніями не може бути застосована в Україні повною мірою внаслідок відсутності фондового ринку, вторинного ринку цінних паперів і низької концентрації капіталу.

У країнах, що розвиваються (наприклад, Туреччина, Індія), легка промисловість була оголошена пріоритетним напрямом для розвитку національної економіки. У більшості з них розроблені програми інноваційного 
розвитку підгалузей легкої промисловості, які включають у себе заходи державної підтримки виробників. Узагальнення досвіду цих країн щодо інституціонального забезпечення у сфері інноваційних процесів в легкій промисловості зводиться до таких напрямів.

1. Податкове та митне регулювання. У Китаї виробникам продукції легкої промисловості надається пільговий режим оподаткування. У Туреччині ввезене для галузі обладнання не обкладається митом і ПДВ. У спеціальній економічній зоні «Онтустік» Республіки Казахстан передбачається повністю звільнити від корпоративного прибуткового податку організації текстильної та швейної галузей у межах інноваційноінвестиційних проектів зі створення нових виробництв $[14$, с. 242]. Щодо ситуації в нашій державі, то, наприклад, згідно з Угодою України та Ізраїлю повинні скасувати всі мита на імпорт товарів, які класифікуються в групах 1-97 Гармонізованої системи.

2. Пряма державна підтримка підприємств-ексnортерів. У Туреччині експортерам надаються цільові пільгові кредити, повне або часткове повернення податків, включених у вартість експортної продукції, часткова компенсація витрат на наукові розробки (дослідження) щодо підвищення якості експортних виробів, страхування експортних операцій тощо.

3. Створення інфраструктури бізнесу. Китайські провінції і міста спеціалізуються на випуску певних видів виробів (тканини, трикотаж, панчішношкарпеткові вироби, одяг для жінок тощо). Для підтримки і підвищення конкурентоспроможності продукції, створення інноваційної основи розвитку галузі влади провінцій сприяють формуванню на своїх територіях розвитку інфраструктури бізнесу технопарків, що включають в себе центри перевірки якості, сервісні, навчальні, інформаційні, логістичні центри та центри автоматизованого проектування моделей, науково-дослідних інститутів, що вивчають властивості тканин.

4. Сприяння оновленню устаткування і технологій. Наприклад, в Індії діє програма оновлення технологій для текстильної та джутової галузей легкої промисловості. Особливістю схеми $є$ компенсація кредитної компанії (5\%), що видала кошти підприємствам на оновлення технологій. Відсотки по закупівлі машин, зроблених на низькому технологічному рівні, не відшкодовуються. Виділяються концесійні позики на оновлення обладнання і технології [15, с. 181].

Бурхливий розвиток виробництв легкої промисловості в країнах, що розвиваються, за значної державній підтримці вплинув на перерозподіл продуктивних сил галузі. У розглянутих країнах також присутня інтегрована співпраця 3 конкурентами, між якими існують зв'язки зі спільного ведення наукових і технічних розробок, покликаних удосконалювати продукцію галузі. Ці підходи дозволили б в Україні проводити політику інтенсивної реструктуризації текстильної галузі та домогтися значних результатів у експансії текстильної продукції на світовий ринок.
За результатами дослідження зарубіжного досвіду та аналізу учасників і напрямів інтегрованого розвитку вітчизняних підприємств легкої промисловості запропоновано систему інституціонального забезпечення на основі державного регулювання (рис. 1).

Особливо важливе місце серед інструментів політики модернізації української економіки у сфері залучення іноземних інвестицій, на нашу думку, займає податкова політика. Вважаємо, що необхідно широко використовувати звільнення від податків на певний період. Низка пільг повинна спрямовуватися на впровадження високих технологій та збільшення експорту продукції. При цьому підприємства легкої промисловості повинні користуватися і митними пільгами. Також слід сформувати полегшений процес створення підприємств за участю іноземного капіталу в легкій промисловості і встановлення пільгового інвестування в особливих економічних зонах для високотехнологічних підприємств. Наприклад, зі світового досвіду відомі і створені вільні торгові зони, спеціальні економічні зони, відкриті міста, зони розвитку економіки i техніки, зони розвитку високих технологій тощо.

3 огляду на те, що нині рівень технологічного розвитку надає досить широкий спектр способів обміну інформацією, компаніям необхідно регламентувати і цей аспект взаємин із метою запобігання ризиків витоку інформації.

Висновки. Інтегрований розвиток породжує синергізм ефективності діяльності, що виявляється в ефекті від єднання бізнес-процесів і потенціалів суб'єктів господарювання. Основними напрямами формування інституціонального забезпечення для підприємств текстильної та швейної промисловості України має бути сприяння створенню внутрішньофірмових корпоративних мереж. На підприємствах текстильного і швейного виробництв необхідно розвивати корпоративні відносини у внутрішньому бізнес-середовищі підприємств за допомогою розроблення і впровадження кодексів корпоративної етики та корпоративної поведінки. Кодекси допоможуть сформувати бажану корпоративну культуру; розуміння партнерами організації та персоналом загальних призначень і цілей, стратегій і засобів їх досягнення; визначення спільних цінностей, які підтримуються керівництвом і персоналом компанії. Ефективне інституціональне забезпечення інтегрованого розвитку дасть змогу побудувати ефективну систему зовнішніх і внутрішніх комунікацій, підвищить інвестиційну привабливість підприємств, поліпшить їхню репутацію, а отже, підвищить рівень конкурентоспроможності.

Інституціональне забезпечення розвитку підприємств легкої промисловості в контексті його інтегрованості дає змогу реалізувати такі можливості, як:

- формування інтегрованого інформаційного забезпечення;

- розширення ринків збуту, зокрема, через експорт;

- проведення ефективної кадрової політики;

- мобілізація оборотних коштів, що дає змогу економити на банківському кредиті; 


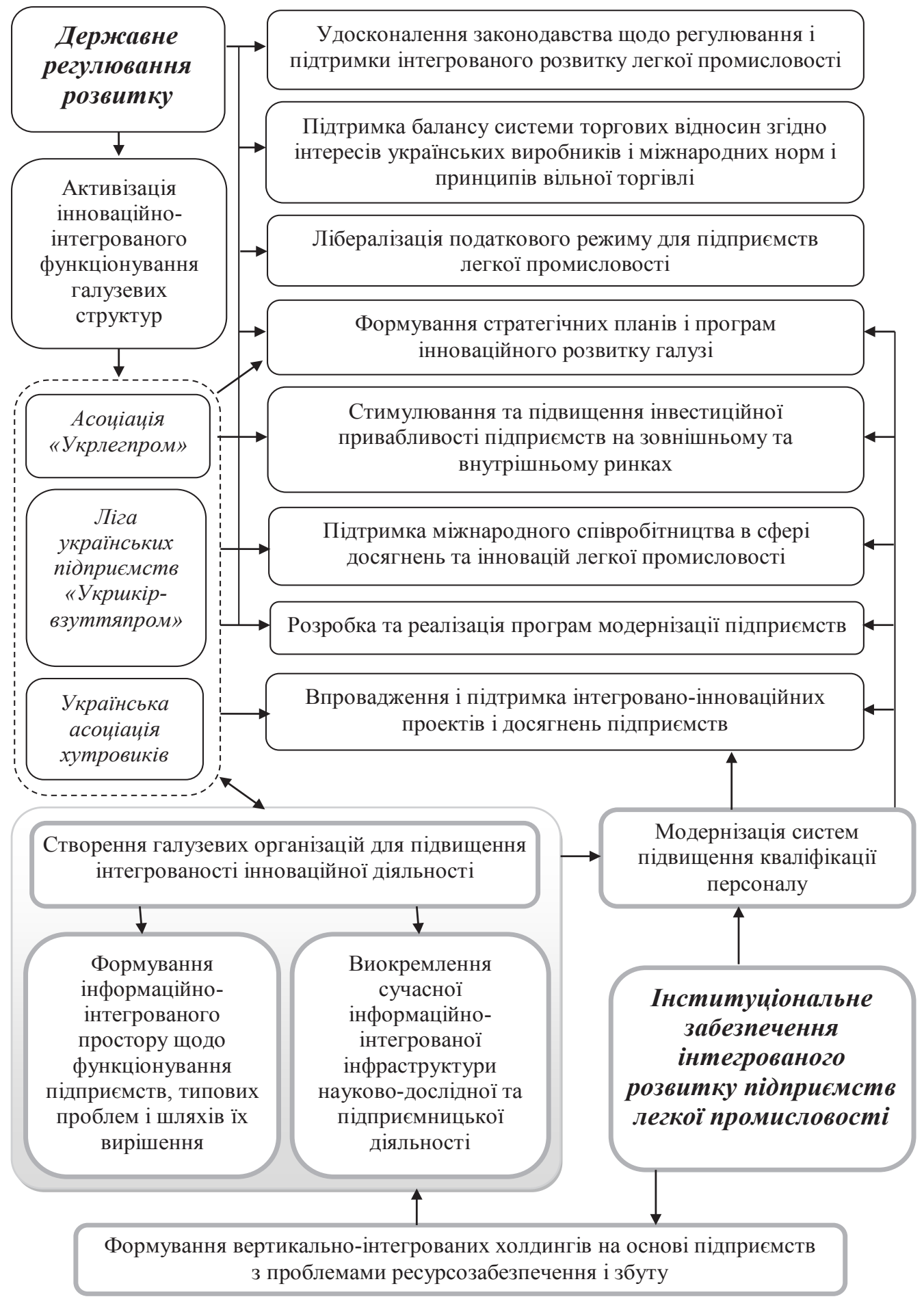

Рис. 1. Інституціональне забезпечення державного регулювання інтегрованого розвитку підприсмств легкої промисловості України

Джерело: сформовано автором

- комплексне технічне переозброєння виробництв, орієнтованих на випуск конкурентоспроможної продукції;

- підвищення оперативності виконання замовлень на продукцію на базі інформаційних технологій проектування напівфабрикатів і готової продукції;

- підвищення якості шляхом освоєння більш склад- ної продукції на основі наукомістких технологій відповідно до напрямів швидкоплинної моди і вимог внутрішнього та зовнішнього ринків, а також її конкурентоспроможності;

- освоєння виробництва товарів народного споживання із заданим комплексом функціональних властивостей (гігієнічних, лікувальних тощо). 
Список літератури:

1. Gardas B.B., Raut R.D., Narkhede B. Modelling the challenges to sustainability in the textile and apparel (T\&A) sector: A Delphi-DEMATEL approach. Sustainable Production and Consumption. 2018. T. 15. Pp. 96-108.

2. Заріцька Н.М. Структурно-динамічний аналіз сучасного стану розвитку легкої промисловості України. Економіка та підприємництвво. 2019. № 42. С. 127-139.

3. Копельчук В. П. Механізм покращення інвестиційного потенціалу підприємств легкої промисловості. Вісник Хмельницького національного університету. 2019. С. 288.

4. Tsai W. H. Green production planning and control for the textile industry by using mathematical programming and industry 4.0 techniques. Energies. 2018. T. 11. Vol. 8. P. 2072.

5. Дейнеко Л. В., Кушніренко О.М., Ципліцька О.О. Впровадження СМАРТ технологій в текстильній та фешн індустрії. KyivTex\&Fashion: матеріали III міжн. наук.-практ. конф. текстильних та фешн технологій, м. Київ, 31 жовтня 2019 р. Київ: КНУТД, 2019. С. 15-20.

6. Munir K., Ayaz M., Levy D.L., Willmott H. The role of intermediaries in governance of global production networks: Restructuring work relations in Pakistan's apparel industry. Human Relations. 2018. Vol. 4. Pp. 560-583.

7. Федорак В. І. Сучасні тенденції інноваційного розвитку підприємств легкої промисловості в умовах глобалізації. Вчені записки університету КРОК. Серія: Економіка. 2019. № 2. С. 231.

8. Збаразська Л.О. Напрями стратегії розвитку «смарт» промисловості в українських реаліях. Економіка промисловості. 2019. Т. 86. № 2. С. 12.

9. Mohiuddin M., Rashid M.M., Al Azad M.S., Su Z. Mohiuddin M. et al. Back-shoring or re-shoring: determinants of manufacturing offshoring from emerging to least developing countries (LDCs). International Journal of Logistics Research and Applications. 2019. Vol. 1. P. 78-97.

10. Ogai Y., Matsumura Y., Hoshino Y. Changing structures of B2B networks in the Japanese textile and apparel industry. Fashion and Textiles. 2020. Vol. 1. P. 1-20.

11. Peters R. Future Expectations of the German Textile Industry: The Role of Tradition on the Threshold of the Fourth Industrial Revolution. RWTH AACHEN. 2019. P. 8-16.

12. Le Q. A., Tran V. A., Nguyen Duc B. L. The Belt and Road Initiative and Its Perceived Impacts on the Textile and Garment Industry of Vietnam. Journal of Open Innovation: Technology, Market, and Complexity. 2019. Vol. 3. P. 59.

13. Stanojevic S., Bin Q., Jian C. Sino-EU15 Export Competition in Central and Eastern Europe: Is China Crowding Out Exports from the EU15? Eastern European Economics. 2020. Vol. 3. P. 264-282.

14. Ukubassova G. S., Toksanova A. N., Galieva A. K., Amirbekova A. B. The governmental support of the light industry in modern integration condition. Karaganda University Bulletin. 2019. Vol. 2(94). P. 242.

15. Abdullazizova K. N. Foreign experience of development of textile industry. Theoretical \& Applied Science. 2018. Vol. 3. P. 178-183.

\section{References:}

1. Gardas B.B., Raut R.D., Narkhede B. (2018). Modelling the challenges to sustainability in the textile and apparel (T\&A) sector: A Delphi-Dematel approach. Sustainable Production and Consumption, vol. 15, pp. 96-108.

2. Zaritska N. (2019). Strukturno-dynamichnyi analiz suchasnoho stanu rozvytku lehkoi promyslovosti Ukrainy [Structural and dynamic analysis of the current state of development of light industry in Ukraine]. Economics and entrepreneurship, vol. 42, pp. 127-139.

3. Kopelchuk V. (2019). Mekhanizm pokrashchennia investytsiinoho potentsialu pidpryiemstv lehkoi promyslovosti [Mechanism of improving the investment potential of light industry enterprises]. Bulletin of Khmelnytsky National University, p. 288.

4. Tsai W. H. (2018). Green production planning and control for the textile industry by using mathematical programming and industry 4.0 techniques. Energies, vol. 11, no. 8, p. 2072.

5. Deineko L.V., Kushnirenko O.M., Tsyplitska O.O. (2019). Vprovadzhennia SMART tekhnolohii v tekstylnii ta feshn industrii [Implementation of SMART technologies in the textile and fashion industry]. Proceedings of the KyivTex\&Fashion (Kyiv, October 31, 2019). Kyiv: KNUTD, pp. 15-20.

6. Munir K., Ayaz M., Levy D.L., Willmott H. (2018). The role of intermediaries in governance of global production networks: Restructuring work relations in Pakistan's apparel industry. Human Relations, vol. 71, no. 4, pp. 560-583.

7. Fedorak V. (2019). Suchasni tendentsii innovatsiinoho rozvytku pidpryiemstv lehkoi promyslovosti v umovakh hlobalizatsii [Modern tendencies of innovative development of light industry enterprises in the conditions of globalization]. Scientific notes of KROK University. Series: Economics, vol. 2, p. 231.

8. Zbarazska L.O. (2019). Napriamy stratehii rozvytku «smart» promyslovosti v ukrainskykh realiiakh [Directions of strategy of development of "smart" industry in the Ukrainian realities]. Industrial economics, vol. 2, p. 12.

9. Mohiuddin M., Rashid M. M., Al Azad M. S., Su Z. (2019). Back-shoring or re-shoring: determinants of manufacturing offshoring from emerging to least developing countries (LDCs). International Journal of Logistics Research and Applications, vol. 22, no. 1, pp. 78-97.

10. Ogai Y., Matsumura Y., Hoshino Y. (2020). Changing structures of B2B networks in the Japanese textile and apparel industry. Fashion and Textiles, vol. 7, no. 1, pp. 1-20.

11. Peters R. (2019). Future Expectations of the German Textile Industry: The Role of Tradition on the Threshold of the Fourth Industrial Revolution. RWTH AACHEN, pp. 8-16. 
12. Le Q.A., Tran V.A., Nguyen Duc B.L. (2019). The Belt and Road Initiative and Its Perceived Impacts on the Textile and Garment Industry of Vietnam. Journal of Open Innovation: Technology, Market, and Complexity, vol. 5, no. 3, p. 59.

13. Stanojevic S., Bin Q., Jian C. (2020). Sino-EU15 Export Competition in Central and Eastern Europe: Is China Crowding Out Exports from the EU15? Eastern European Economics, vol. 58, no. 3, pp. 264-282.

14. Ukubassova G.S., Toksanova A.N., Galieva A.K., Amirbekova A.B. (2019). The governmental support of the light industry in modern integration condition. Karaganda University Bulletin, vol. 2, no. 94, p. 242.

15. Abdullazizova, K.N. (2018). Foreign experience of development of textile industry. Theoretical \& Applied Science, vol. 3, pp. 178-183.

\title{
ИНСТИТУЦИОНАЛЬНОЕ ОБЕСПЕЧЕНИЕ ИНТЕГРИРОВАННОГО РАЗВИТИЯ ПРЕДПРИЯТИЙ ЛЕГКОЙ ПРОМЫШЛЕННОСТИ
}

\begin{abstract}
Целью исследования является определение направлений повышения эффективности институционального обеспечения государственного регулирования интегрированного развития отечественных предприятий легкой промышленности с учетом зарубежного опыта. Установлено, что в развивающихся странах-лидерах отрасли легкая промышленность была объявлена приоритетным направлением для развития национальной экономики. Предложено авторское видение институционального обеспечения государственного регулирования интегрированного развития предприятий легкой промышленности Украины. Сформированы рекомендации по повышению уровня институционального обеспечения интегрированного развития отечественных компаний. Определен ряд возможностей, которые позволяет реализовать институциональное обеспечение развития предприятий легкой промышленности в контексте его интегрированности.
\end{abstract}

Ключевые слова: интегрированный развитие, институциональное обеспечение, конкуренция, эффективность, управление.

\section{INSTITUTIONAL SUPPORT OF INTEGRATED DEVELOPMENT OF LIGHT INDUSTRY ENTERPRISES}

The purpose of this research was to determine the directions of increasing the efficiency of the institutional provision of the state regulation of the integrated development of domestic enterprises of light industry, taking into account foreign experience. The institutional support of development in the context of enterprise integration was identified as a transition to the change of the intra-industry structure of production in the direction of increasing the output of a wide range of products that could be competitive in both domestic and world markets, mobilization of working capital and implementation of a single investment industrial policy that would allow to make production competitive. The main features of world experience in institutional support of light industry development were defined. It was established that in developing countriesleaders of the industry, light industry had been declared as a priority area for the development of the national economy. The directions of institutional support in the field of innovation processes in light industry in the context of the experience of developing countries were identified: tax and customs regulation, direct state support to exporting enterprises, creation of business infrastructure, promotion of equipment and technology renewal. The author's vision of institutional support of state regulation of light industry integrated development in Ukraine was proposed. The recommendations on increasing the level of institutional support of domestic companies' integrated development were formulated. The main directions of formation of institutional support for enterprises of textile and sewing industry of Ukraine should be assistance in creation of interfirm corporate networks. At the enterprises of textile and sewing manufacture it was necessary to develop the corporate integrated relations in internal and external business environment of the enterprises by working out and introduction of codes of corporate ethics and corporate behavior. A number of opportunities were identified for the institutional support of light industry enterprises in the context of their integrated development.

Key words: integrated development, institutional support, competition, efficiency, management. 